(C) 2018, THE AUTHORS. Published by FASS Inc. and Elsevier Inc. on behalf of the American Dairy Science Association ${ }^{\circledR}$.

This is an open access article under the CC BY-NC-ND license (http://creativecommons.org/licenses/by-nc-nd/3.0/).

\title{
Evaluation by employees of employee management on large US dairy farms
}

\author{
Phillip T. Durst, ${ }^{* 1}$ Stanley J. Moore, ${ }^{*}$ Caroline Ritter, $†$ and Herman W. Barkema† \\ *Michigan State University Extension, Michigan State University, East Lansing 48824 \\ †Department of Production Animal Health, Faculty of Veterinary Medicine, University of Calgary, Calgary, AB T2N 1N4, Canada
}

\begin{abstract}
Employees, many of whom are not native English speakers, perform the majority of work on large US dairy farms. Although management of employees is a critical role of dairy owners and managers, factors that improve employee engagement and retention are not well known. Objectives were to (1) identify key dairy farm employee management issues based on employee perceptions, (2) evaluate strengths and weaknesses of farms based on employee responses, (3) investigate differences between Latino and English-speaking employees, and (4) investigate differences in perception between employers and employees. Employees from 12 US dairy farms (each with a minimum of 10 employees) were interviewed by phone following a questionnaire provided. Employees provided their responses to 21 Likert scale questions and 8 open-ended questions. There was a wide range in employee turnover among farms $(<10$ to $>100 \%$ ). Latino employees had much shorter tenure and were more often employed in milking and livestock care than English-speaking employees. Employee perceptions differed among farms regarding whether they would recommend their farm as a place to work, teamwork within the dairy, whether rules were fairly applied, availability of tools and equipment, clear lines of supervision, and recognition for good work in the previous $15 \mathrm{~d}$. Latino employees $(\mathrm{n}=91)$ were more positive in many of these measures than their Englishspeaking counterparts $(\mathrm{n}=77)$ but less often provided ideas to their employer on how to improve the business. Employers, surveyed on how they thought their employees would answer, underestimated employee responses on several questions, particularly the interest of employees in learning about dairy. When asked to cite 3 goals of the operation, there were differences among owners, managers, and employees. Although employees rated their commitment to the farm and their interest in learning as high, based on turnover, there was an obvious disparity between reality and ideal employee
\end{abstract}

Received February 15, 2018.

Accepted April 14, 2018.

${ }^{1}$ Corresponding author: durstp@msu.edu management. Consequently, employers should act on identified management shortfalls to improve employee retention.

Key words: employee, management, turnover

\section{INTRODUCTION}

Large dairy farms (>500 cows) constitute only $6.7 \%$ of US dairy farms but account for $64 \%$ of annual milk production (USDA National Agricultural Statistics Service, 2014). Dairy herd size has increased in past decades and is expected to continue increasing (Barkema et al., 2015); consequently, the importance of employees will continue to grow. Dairy labor is increasingly provided by immigrants (Schenker and Gunderson, 2013), with $51 \%$ of all US dairy labor estimated to be foreignborn employees (Adcock et al., 2015). The ability of those workers to speak English may be limited (Maloney et al., 2016). Furthermore, they are less likely to understand farm goals or receive primary training from other employees compared with their English-speaking counterparts (Erskine et al., 2015). Compounding the challenge of employee management is that dairy employees, whether immigrants or locals, are increasingly likely to lack a farm background (Fuhrman, 2002).

The cost of employee turnover on dairy farms is high (Billikopf and González, 2012). Furthermore, high turnover on some farms makes it more difficult to hire new workers. Employee turnover is a complex issue but is affected by management of employees (Daouk-Öyry et al., 2014). Labor supply, including migrant labor, has tightened in the last few years. Based on US Census Bureau data, there was a $62 \%$ decrease in average number of annual arrivals from Mexico in 2010 to 2014 compared with 2000 to 2009 (Camarota and Zeigler, 2016). Due to immigration policies, birth rates, other job opportunities, and changes in what work people are willing to do, it is anticipated that fewer individuals will be available for dairy farm work in the future.

Staffing a dairy farm is more than just having an employee in each position; ideally, it is having productive, high-performing employees. Such employees have been termed "engaged," dating back to the work of Kahn (1990), who started with the premise that employees can use varying degrees of themselves physi- 
cally, cognitively, and emotionally in the roles they perform. Billikopf (2003) described workers who were mentally absent or disengaged - that is, the worker was present but their mind was somewhere else. Managing employees is recognized as a principal function of farm management (Hadley et al., 2002; Hagevoort et al., 2013), but it is still an area in need of greater development by agricultural owners and managers. For farms to be successful in meeting quality, production, and profitability goals, employers must manage people well and employees must be performing their job to the best of their abilities. Relationships between employee management practices and measures of some aspect of herd performance have been reported [e.g., milk quality (Schewe et al., 2015) and milking efficiency (Rodrigues et al., 2005)]. However, relationships between farm employee management and measures of farm profitability have rarely been studied and only occasionally demonstrated (continued training and farm return on assets; Stup et al., 2006). Although farmers overwhelmingly acknowledge the importance of finding and retaining good employees and even of motivating employees with positive feedback (Bewley et al., 2001; Caraviello et al., 2006; Kayitsinga et al., 2017), interest in improving employee management has been limited. A survey of Wisconsin dairy farmers reported that employee management was of little interest to farmers who planned to expand (ranked sixth; Cabrera and Janowski, 2011) and of interest to only one-quarter of farmers who planned to expand.

Employee management varies greatly among farms and has implications on profitability and advancement of the business (Estrada, 2017). Success of dairy businesses will increasingly depend on the employer's ability to develop a competent, motivated, and passionate workforce (Milligan, 2017). Farms that are more effective in employee management will have a sustainable competitive advantage over their peers (Stup et al., 2006; Mugera, 2012). However, what motivates dairy farm employees to stay on the same farm and to do a good job has not been well documented. Objectives were therefore to (1) identify key dairy farm employee management issues based on employee perceptions, (2) evaluate strengths and weaknesses of farms based on employee responses, (3) investigate differences between Latino and English-speaking employees, and (4) investigate how employers and employees differ in perception.

\section{MATERIALS AND METHODS}

\section{Recruitment of Farms}

Dairy farms were recruited by distribution of printed materials and verbal communications at dairy confer- ences and meetings in the state of Michigan and by personal approach in 3 other states: Pennsylvania, New York, and Connecticut. Dairy farm owners participated in the project due to their interest in feedback from their farm's employees and how that feedback could improve their employee management skills. Participation was voluntary. Participation was limited to farms with a minimum of 10 employees to protect anonymity of employees and gather sufficient feedback on each farm. No distinction was made between full-time and part-time employees. Project personnel enrolled farms during a personal visit to the farm. Follow-up phone conversations and email were also used. Each farm owner signed a contract to participate in the project and was paid a project fee based on the number of employees on the farm. Thirteen dairy farms enrolled in the project between November 2012 and May 2014.

The Michigan State University Institutional Research Board reviewed and approved the study as "exempt." The survey instrument was prescreened with extension colleagues and 2 farmers.

\section{Questionnaires}

The employee questionnaire (see Supplemental File S1; https://doi.org/10.3168/jds.2018-14592) included 21 Likert scale questions (scale of 1 to 5 , with descriptors) as well as 8 open-ended questions. Likert scale questions were designed with the most positive response indicated by a 5 (with the exception of Q28, for which 4 answers were possible), and descriptors were used for high and low ratings in all cases and for each rating in some cases. On all Likert scale questions, employees were also invited to provide supporting comments to their answers.

Some questions (e.g., Q5, 6, 25, 26, 28) were about employees' work attitudes, some were about their work environment (e.g., Q13, 14, 15, 16, 17, 18, 19), and others were about their perception of their supervisors' attitudes and behavior (Q20, 21). Thus, the questionnaire attempted to capture various aspects that affected evaluation of the work environment, whether directly or indirectly affected by management, for employees.

A questionnaire was also prepared for employers (owners and managers). The employer questionnaire (Supplemental File S2; https://doi.org/10.3168/jds .2018-14592) had 21 Likert scale questions and 5 open-ended questions that asked them to rate how they thought their employees would respond to each management-related question of the employee questionnaire. Managers who were not owners were asked to complete the survey because of their role in supervising employees even though they too were employees. They were told that they could also complete the employee 
survey if they desired. Because of anonymity of the employee surveys, it is unknown whether any of the managers did.

\section{Data Collection}

Employers. Project personnel held an initial meeting at the farm to review the project and enroll farms. At that time, project personnel administered the employer questionnaire. Employers provided the following additional information: number of employees, number of replacement hires in the past $12 \mathrm{mo}$, number of cows at the beginning and end of the previous year, total employee payroll, and total amount of milk shipped. As the project proceeded, data were collected for more than 1 yr.

Employees. Upon enrollment, paper copies of the employee questionnaire, in English and in Spanish, were provided to the farm owners and managers for distribution to employees. Employees were asked not to fill out the paper questionnaire but instead to familiarize themselves with what would be asked in the phone interview before calling the interviewer. Although some farms assisted with logistics of scheduling calls, employees could decide for themselves whether to participate. Participating farms were assigned a block of days for phone interviews from their employees. During that period, no feedback was provided to employers about how many of their employees called for an interview.

The interviewer identified callers by number, the name of the farm where they worked, and as either English speaking or Latino (Spanish or Portuguese speaking); no record of the caller's identity was collected. One native Spanish-speaking interviewer, also fluent in English and Portuguese, conducted all phone interviews.

The questionnaire was filled out in the interviewee's native language; Spanish and Portuguese responses were thereafter translated into English. For each question in the survey, respondents had the opportunity to provide comments on what the interviewer had recorded.

\section{Statistical Analyses}

Minimum response rate of employees on individual farms was set at $50 \%$ to ensure that sufficient data were obtained. One participating farm was excluded by this criterion because only $22 \%$ of its employees called the interviewer.

Annual employee turnover was defined as the number of employees hired in $1 \mathrm{yr}$ divided by the number of employee positions. To account for change in employees needed based on either growth or reduction in herd size, the intent was that employee positions would be adjusted by 1 position for every change of \pm 50 cows. None of the enrolled farms changed in cow numbers enough to make this adjustment for the interval studied.

Employee results were combined and analyzed across farms, within farms, and by language group. Responses to open-ended questions and comments provided with Likert scale questions helped provide additional information, including management evaluation. Based on employee responses in both Likert rating questions and open-ended questions, areas of employee management weaknesses were identified by employees on those farms.

Responses to the open-ended question "How frequently do you have ideas to improve the business, whether you share them or not?" (Q27 in Supplemental File S1; https://doi.org/10.3168/jds.2018-14592) were divided into 4 categories: (1) frequently have ideas to improve the business (defined as when respondent provided a frequency of at least once a month or a response that indicated very frequently), (2) occasionally (defined as when respondent indicated a frequency of less than once per month or a response that indicated occasionally), (3) never (responses such as "I just do what they tell me to do"), and (4) have ideas but do not share them.

Statistical analyses were done with Stata SE 12 (StataCorp LP, College Station, TX), and $P<0.05$ was considered significant. First, descriptive statistical analyses were performed. Length of tenure between English-speaking and Latino employees was compared using a Student's t-test after logarithmic conversion of the continuously assessed variable (years). Additionally, chi-squared tests were used to assess whether a significantly different number of English-speaking employees stayed for more than $1 \mathrm{yr}$ (or more than $3 \mathrm{yr}$ ) at one farm compared with Latino employees. Comparison of length of tenure across farms was done using 1-way ANOVA.

To compare primary roles on the farm between English-speaking and Latino employees, chi-squared or Fisher's exact test (if any value in the contingency table was $<5$ ) were used. Perceptions and attitudes that were ranked on Likert scales were compared between employees working at the farm for $>1$ yr versus $\leq 1$ yr, between English-speaking and Latino employees, and between employers and employees using Wilcoxon rank-sum tests.

Potential differences among farms were evaluated with a Kruskal-Wallis test (with ties). Frequency of bringing up ideas regarding the farm business between English-speaking and Latino employees was compared using a Wilcoxon rank-sum test and chi-squared test. 
Frequency of employees voicing ideas dependent on the farm was assessed using a Kruskal-Wallis test (with ties).

\section{RESULTS}

Twelve farms averaging 850 cows with an average annual milk yield of $12,677 \mathrm{~kg}$ of milk per cow were included in the analysis (Table 1). These farms had an average of 18 employees, or 1 employee per 48 cows. In total, 168 (79\%) employees participated in the questionnaire; 91 were Latino (86 Spanish speaking, 5 Portuguese speaking) and 77 were English speaking. Of the 12 farms, 9 had both English-speaking and Latino employees, 2 had English-speaking employees only, and 1 had Latino employees only among the respondents.

Annual employee turnover on the farms ranged from 8 to $144 \%$, with 3 farms having annual turnover $\geq 100 \%$ (Table 1). Where possible, employee turnover data from the 2 previous years were collected. Based on these data, turnover presented was representative for the farms. Length of employee tenure also differed among the 12 farms $(P=0.02)$. Overall, employment tenure of Latino employees who were interviewed was considerably shorter than that of English-speaking respondents (Figure 1). More than one-third (35\%) of Latino employees had been on the farm $\leq 1$ yr compared with $18 \%$ of English-speaking employees $(P=0.01)$. Likewise, $57 \%$ of English-speaking respondents had been employed on the farm for $>3 \mathrm{yr}$, whereas only $40 \%$ of Latino employees had been employed for that interval $(P=0.02)$. This difference was more pronounced on some farms.

\section{Employee Management, Strengths and Weaknesses}

Mean employee responses by farm to the Likert scale questions (Table 2) indicated 4 primary areas in which farms were scored lowest by employees: (1) performance feedback (Q16; 3.13), particularly positive feedback (Q22; 3.31); (2) training (Q15; 3.34); (3) open and honest communication with supervisor (Q23; 3.33); and (4) communication of goals (Q11; 3.95). These areas of common management weakness were confirmed by additional comments employees made or by responses to open-ended questions. Comments offered voluntarily on Q16 (frequency of feedback, positive or negative) provided clarification on employee perception. Responses with a message similar to "positive, never; negative, every week" appeared $22 \%$ of the time when any comments were offered on this question.

Employee response to the question about frequency of training to improve skills (Q15) indicated a perception by employees that they had not received much training. Employees on 7 farms (58\%) had an average response $<3$, indicating that training was offered less than once per year ("only when I started" or "never"). Indeed, $11 \%$ ( $\mathrm{n}=18$ ) of employees replied that they had never had training, and $36 \%$ (58) said they were trained only when they started the job.

To the open-ended question "What would you change to make this a better place to work?" (Q9), 121 employees responded. Of those, 25 (21\%) specifically mentioned better communication, usually regarding communication from management but sometimes between employees or to "get everyone on the same page."

Strengths in the workplace environment were also evident from mean responses to the Likert scale ques-

Table 1. Characteristics of the 12 participating dairy farms ${ }^{1}$

\begin{tabular}{|c|c|c|c|c|c|c|c|c|c|}
\hline \multirow[b]{2}{*}{ Farm } & \multirow{2}{*}{$\begin{array}{l}\text { No. of } \\
\text { cows }\end{array}$} & \multirow{2}{*}{$\begin{array}{c}\text { Annual } \\
\text { milk yield } \\
(\mathrm{kg} / \mathrm{cow})\end{array}$} & \multirow{2}{*}{$\begin{array}{c}\text { No. of } \\
\text { employees }\end{array}$} & \multicolumn{2}{|c|}{ Respondents } & \multirow{2}{*}{$\begin{array}{l}\text { No. of English- } \\
\text { speaking } \\
\text { respondents }\end{array}$} & \multirow{2}{*}{$\begin{array}{l}\text { No. of } \\
\text { Latino } \\
\text { respondents }\end{array}$} & \multirow{2}{*}{$\begin{array}{c}\text { Annual } \\
\text { employee } \\
\text { turnover }^{2}(\%)\end{array}$} & \multirow{2}{*}{$\begin{array}{c}\text { Previous year } \\
\text { employee } \\
\text { turnover }(\%)\end{array}$} \\
\hline & & & & No. & $\%$ & & & & \\
\hline 1 & 918 & 12,890 & 22 & 20 & 91 & 13 & 7 & 100 & $\mathrm{NA}^{3}$ \\
\hline 2 & 818 & 12,125 & 23 & 20 & 87 & 9 & $11^{4}$ & 65 & 57 \\
\hline 3 & 880 & 12,371 & 12 & 10 & 83 & 4 & 6 & NA & NA \\
\hline 4 & 1,150 & 12,770 & 28 & 17 & 61 & 4 & 13 & 42 & 13 \\
\hline 5 & 572 & 11,931 & 12 & 9 & 75 & 3 & 6 & 8 & NA \\
\hline 6 & 1,102 & 13,741 & 25 & 22 & 88 & 9 & 13 & 20 & 17 \\
\hline 7 & 1,067 & 14,199 & 18 & 13 & 72 & 13 & 0 & 111 & 88 \\
\hline 8 & 589 & 12,673 & 13 & 9 & 69 & 9 & 0 & 31 & 54 \\
\hline 9 & 868 & 13,568 & 26 & 19 & 73 & 6 & 13 & 46 & 27 \\
\hline 10 & 580 & 10,088 & 11 & 6 & 55 & 0 & 6 & 18 & $\mathrm{NA}$ \\
\hline 11 & 974 & 13,086 & 13 & 13 & 100 & 3 & 10 & 144 & 63 \\
\hline 12 & 680 & NA & 10 & 10 & 100 & 4 & 6 & NA & NA \\
\hline Total & 850 & 12,677 & 213 & 168 & 80 & $77(46 \%)$ & $91(54 \%)$ & & \\
\hline
\end{tabular}

\footnotetext{
${ }^{1}$ All data for last complete year.

${ }^{2}$ Number of hires in the year divided by number of positions.

${ }^{3}$ Data not available from farm.

${ }^{4}$ Includes 5 Portuguese-speaking employees.
} 
tions. Three areas in particular were noted: knowing what is expected (Q13; 4.55), feeling they can talk with their supervisor (Q18; 4.39), and independence to do their job (Q19; 4.40). In addition, the highest mean response was to 2 questions that were self-evaluations by the employee: their commitment to the success of the business $(\mathrm{Q} 26 ; 4.62)$ and their interest in learning (Q25; 4.61).

\section{Differences Among Farms}

Mean employee response by farm on Likert scale questions among the 12 farms differed $(P<0.05)$ for 6 questions, 5 of which related to the workplace environment and management: teamwork (Q8; range: 2.7-4.8), rules being applied fairly (Q10; range: $3.4-5.0$ ), having tools and equipment (Q14; range: 2.5-4.5), having clear lines of supervision (Q17; range: 2.9-4.9), and frequency of recognition in the past $15 \mathrm{~d}$ (Q22; range: 1.6-3.6; Table 2). The mean response to the question of whether employees would recommend their workplace to others (Q7) also differed among farms, with a range of 3.1 to 4.8 .

Ratings on those questions implied that some work teams were not functioning well and that there were farms where teams functioned very well. Employee comments recorded by the interviewer highlighted the effect of dysfunctional teams ("Co-workers don't help each other. If something breaks, people try to find somebody to blame"; "Between people in my shift, the relationship is good, but with the day shift, not so good. There are a lot of Mexican people and they don't speak English; we can't communicate") and highly functional teams ("We get along well, we help each other"; "We work really well") on farms.

Although employee ratings varied across farms and there were differences among farms depending on employees' answers, no farm consistently received the highest ratings, nor did 1 farm consistently rate lowest on all questions (Table 2). Although employee responses to some questions were higher for some farms, $83 \%$ of farms had the highest mean score for at least 1 question, whereas $58 \%$ of farms had the lowest mean score for 1 question.

\section{Differences Between English-Speaking and Latino Employees}

Latino employees were more likely to be employed as milkers than English-speaking employees (68 vs. $23 \%$; Table 3). English-speaking employees were more likely to be involved in crop production or equipment and maintenance (16 vs. $2 \%$ ) than Latino employees. More English-speaking employees (18 vs. 4\%) stated that their primary responsibility was a management role (herdsman, dairy manager, feed manager, crop manager).

When examining employee responses by language group across farms, there were differences in responses to several questions (Table 4). Latino employees

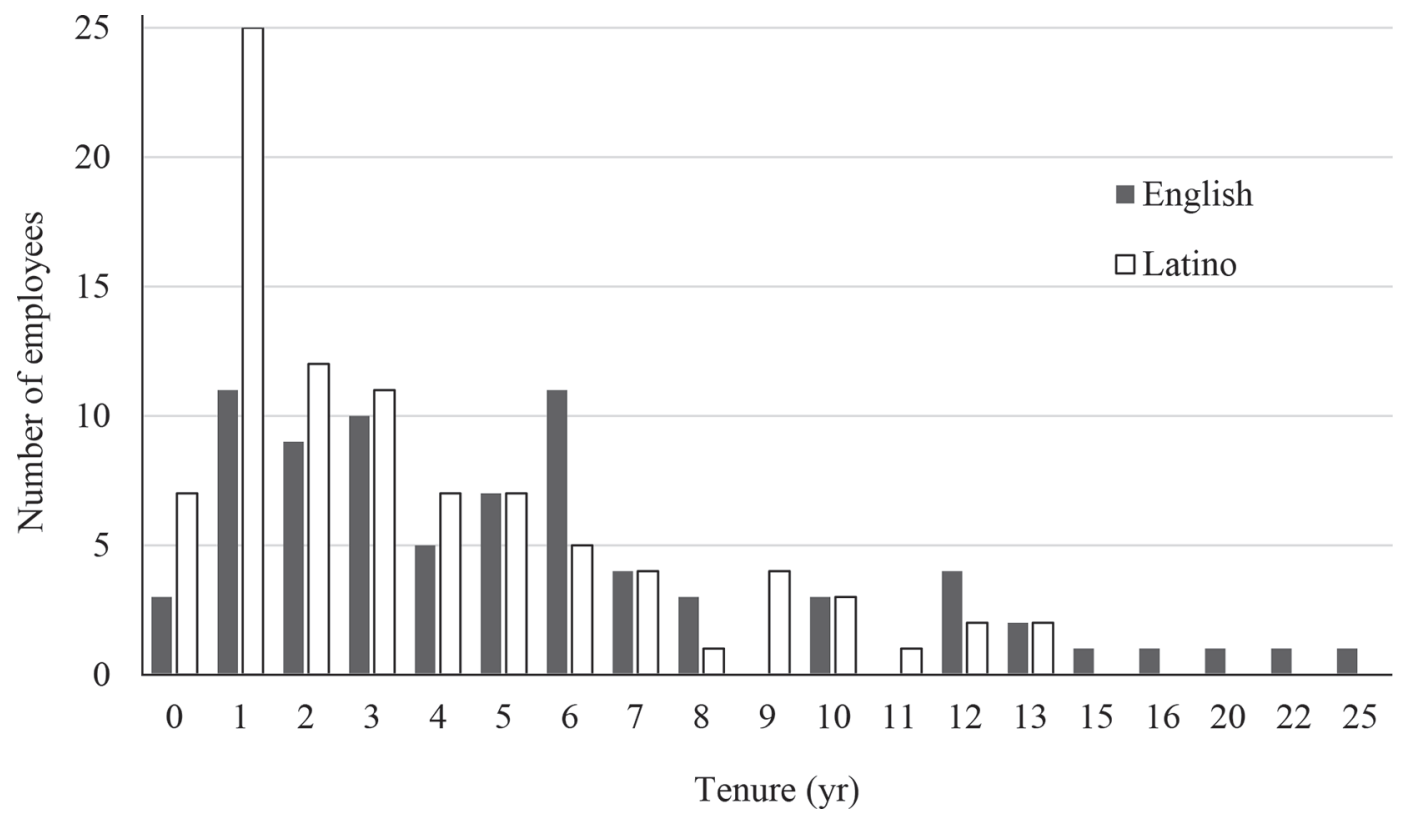

Figure 1. Duration (years) that English-speaking and Latino (Spanish-speaking, $\mathrm{n}=86$; Portuguese-speaking, $\mathrm{n}=5$ ) employees have worked on 12 participating dairy farms. 


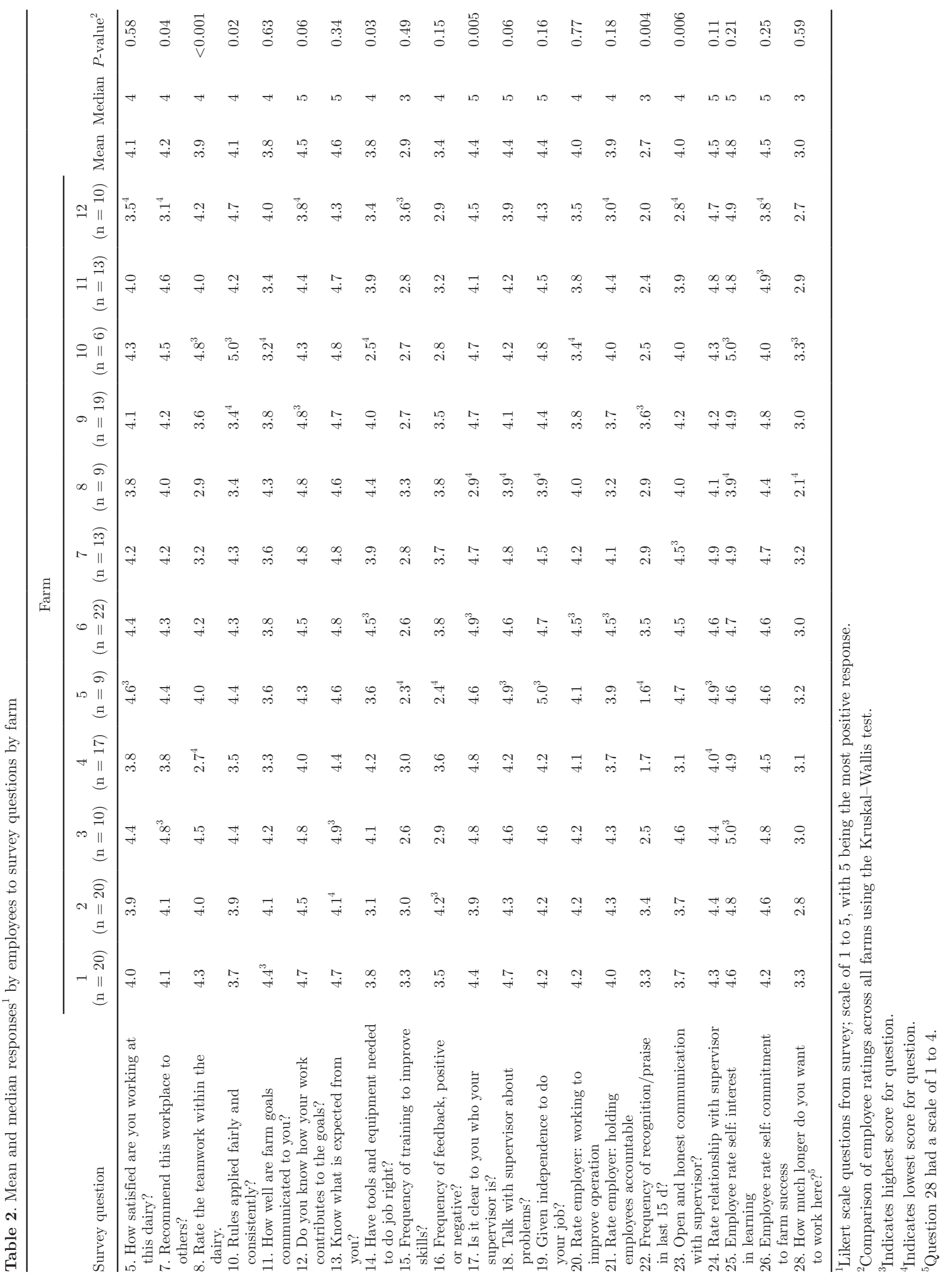


Table 3. Primary areas of responsibility of farm employee respondents by language

\begin{tabular}{|c|c|c|c|c|c|}
\hline \multirow[b]{2}{*}{ Primary role } & \multicolumn{2}{|c|}{$\begin{array}{l}\text { English-speaking } \\
\text { employees }\end{array}$} & \multicolumn{2}{|c|}{$\begin{array}{l}\text { Latino } \\
\text { employees }^{2}\end{array}$} & \multirow[b]{2}{*}{$P$-value ${ }^{3}$} \\
\hline & No. & $\%$ & No. & $\%$ & \\
\hline Milking & 18 & 23 & 62 & 68 & $<0.001$ \\
\hline Livestock care $^{4}$ & 19 & 25 & 41 & 45 & $<0.01$ \\
\hline Feeding & 13 & 17 & 5 & 5 & 0.02 \\
\hline Calves & 4 & 5 & 13 & 14 & 0.07 \\
\hline Crops & 12 & 16 & 2 & 2 & $<0.01$ \\
\hline Management/herdsperson & 14 & 18 & 4 & 4 & $<0.01$ \\
\hline Equipment/building maintenance & 20 & 26 & 0 & 0 & $<0.001$ \\
\hline
\end{tabular}

responded more positively to questions about recommending the workplace to others (Q7), teamwork (Q8), rules being fairly applied (Q10), and clear supervision (Q17). They indicated, at a level greater than Englishspeaking employees, that their employer held employees accountable (Q21) and that they themselves were interested in learning about dairy (Q25). English-speaking employees responded more positively to only 1 question: knowing how their work relates to the goals of the farm (Q12). Latino and English-speaking employees rated themselves as likely to be satisfied, as knowledgeable about the farm goals, as clear on expectations, as having tools and equipment to do the job, as given as much independence to do their job, as likely to consider their employer improving the operation, as frequent in receiving recognition within the past $15 \mathrm{~d}$, as having open and honest communication with their employer, as having a good relationship with their employer, and as committed to the success of the operation. They also indicated receiving training as frequently, receiving performance feedback as frequently, and being able to talk with their supervisor as readily. When assessing differences of employee responses depending on tenure, a difference was present for only 2 measures: employees of short job tenure rated employee teamwork higher (4.3 vs. $3.7 ; P<0.001)$ and intention to stay lower $(2.7$ vs. $3.1 ; P=0.03)$.

\section{Differences Between Employees and Managers in Responses}

Employer questionnaires were completed by 22 farm owners and managers. On 7 farms (58\%), employer questionnaires were completed by more than $1(2-4)$ employers. Overall, employers generally underestimated responses by employees (Table 4) -for example, regarding employee satisfaction (3.5 vs. 4.1), interest in learning (3.3 vs. 4.9 ), employee commitment to the success of the farm operation (3.6 vs. 4.5), and employee relationship with the supervisor (3.4 vs. 4.5). However, on 3 questions, employers overestimated how employees would respond: recognition or praise within the past 15 d (3.5 vs. 2.8), training to improve skills (3.4 vs. 2.9), and having tools and equipment to do the job properly (4.2 vs. 3.9). Responses differed between employers on the same farm, by generation, between owners and managers, and between spouses. They sometimes responded differently in their estimation of what employees would say, and they often did not list the same goals for the farm (Table 5). Sometimes they acknowledged a lack of unity in management.

Employees were asked (Q28) "If it were up to you, how much longer would you want to remain in a position at this farm?" They could respond with 1 of 4 answers: $1 \mathrm{yr}$ or less, 2 to $3 \mathrm{yr}, 4$ to $5 \mathrm{yr}$, or until retirement. More than one-third of employees were designated short-timers by their response: $12 \%$ (20) replied $\leq 1 \mathrm{yr}$, and $22 \%$ (36) replied 2 to 3 yr. Fewer than half, $43 \%$ (71), replied until retirement. Yet when employers were asked what percentage of their employees they hoped would make a career at the farm, the mean response was $67 \%$ of employees.

\section{Open-Ended Questions}

Employees stated that the farm goals had been communicated to them (average response $=3.8$; Table 4 ), yet when asked to list some of the farm goals they remembered, the ability to do so and the specificity of the goals was lacking (Table 5). The most common response $(29 \%)$ was something similar to "do a good job and keep things clean." Only 16 employees (10\%) cited a goal that was specific in regard to bulk tank SCC, milk production, number of cows milked, cows milked per 
Table 4. Responses to Likert scale questions (scale of 1 to 5 , with 5 being the most positive response) by employees and employers (owners and managers) ${ }^{1}$

\begin{tabular}{|c|c|c|c|c|c|c|}
\hline Survey question & $\begin{array}{l}\text { English } \\
\text { speaking } \\
(\mathrm{n}=77)\end{array}$ & $\begin{array}{c}\text { Latino }^{2} \\
(\mathrm{n}=91)\end{array}$ & $P$-value ${ }^{3}$ & $\begin{array}{c}\text { All } \\
\text { employees } \\
(n=168)\end{array}$ & $\begin{array}{c}\text { Owners/ } \\
\text { managers }^{4} \\
(\mathrm{n}=22)\end{array}$ & $P$-value ${ }^{5}$ \\
\hline 5. How satisfied are you working at this dairy? & 4.0 & 4.1 & 0.41 & 4.1 & 3.5 & $<0.01$ \\
\hline 7. Would you recommend this workplace to others? & 4.0 & 4.2 & 0.03 & 4.3 & 3.8 & 0.01 \\
\hline 8. Rate the teamwork within the dairy. & 3.6 & 3.8 & $<0.01$ & 4.0 & 3.2 & 0.01 \\
\hline 10. Are rules applied fairly and consistently? & 3.8 & 4.0 & 0.01 & 4.2 & 3.7 & 0.02 \\
\hline 11. How well are farm goals communicated to you? & 3.8 & 3.8 & 0.31 & 3.8 & 3.1 & $<0.01$ \\
\hline 12. Do you know how your work contributes to the goals? & 4.7 & 4.5 & 0.04 & 4.4 & 3.8 & $<0.01$ \\
\hline 13. Do you know what is expected from you? & 4.5 & 4.6 & 0.20 & 4.6 & 4.0 & $<0.01$ \\
\hline 14. Do you have tools and equipment needed to do job right? & 3.8 & 3.9 & 0.29 & 3.9 & 4.2 & 0.50 \\
\hline 15. Frequency of training to improve skills? & 2.9 & 2.9 & 0.96 & 2.9 & 3.4 & 0.04 \\
\hline 16. Frequency of feedback, positive or negative? & 3.5 & 3.5 & 0.69 & 3.5 & 3.1 & 0.24 \\
\hline 17. Is it clear to you who your supervisor is? & 4.0 & 4.4 & $<0.01$ & 4.8 & 3.5 & $<0.01$ \\
\hline 18. Do you talk with supervisor about problems? & 4.4 & 4.4 & 0.83 & 4.4 & 4.0 & 0.04 \\
\hline 19. Are you given independence to do your job? & 4.3 & 4.4 & 0.11 & 4.5 & 3.8 & $<0.01$ \\
\hline 20. Rate employer: working to improve operation & 4.1 & 4.1 & 0.39 & 4.0 & 4.0 & 0.33 \\
\hline 21. Rate employer: holding employees accountable & 3.8 & 4.0 & $<0.01$ & 4.2 & 3.4 & $<0.01$ \\
\hline 22. Frequency of recognition/praise in last $15 \mathrm{~d}$ ? & 2.9 & 2.8 & 0.66 & 2.8 & 3.5 & 0.06 \\
\hline 23. Open and honest communication with supervisor? & 4.0 & 3.9 & 0.61 & 3.9 & 3.6 & 0.04 \\
\hline 24. Rate relationship with supervisor & 4.4 & 4.4 & 0.68 & 4.5 & 3.4 & $<0.01$ \\
\hline 25. Employee rate self: interest in learning & 4.6 & 4.7 & $<0.01$ & 4.9 & 3.3 & $<0.01$ \\
\hline 26. Employee rate self: commitment to farm success & 4.6 & 4.5 & 0.97 & 4.5 & 3.6 & $<0.01$ \\
\hline 28. How much longer do you want to work here? & 3.1 & 3.0 & 0.06 & 2.8 & & \\
\hline
\end{tabular}

${ }^{1}$ Refer to Supplemental Files S1 and S2 (https://doi.org/10.3168/jds.2018-14592) for answer options.

${ }^{2}$ Spanish speaking $(\mathrm{n}=86)$ and Portuguese speaking $(\mathrm{n}=5)$.

${ }^{3}$ Comparing ratings of English-speaking versus Latino employees.

${ }^{4}$ Evaluation by owners and managers of what they believe their employees would say.

${ }^{5}$ Comparing ratings from owners and managers with ratings from employees.

hour, or mortality rate of calves. Most responses (90\%) were general, with terms such as "lower" or "more." One employee said, in response to the question about communication of farm goals, "All companies usually put up charts, but here there is nothing. We come here like donkeys to do what we are told to do."

Employers (owners and managers) were also asked to list 3 goals of the operation. Of 67 goals written by 22 employers on the questionnaire, only 1 was specific: "Labor efficiency: milk/worker $>1$ million pounds consistently; milk quality: $<150,000$ SCC." Employers were asked to rate themselves on setting goals (Q18), where $1=$ there are not any long-term goals and $5=$ goal setting is regular and we work to achieve those goals. The mean response was 3.59 , with $40 \%$ of employers replying with a score $<4$. They also rated themselves on communicating goals to employees (Q8). The mean response of 3.1 was tied with frequency of feedback (Q13) as the lowest score among responses.

When the goals listed by owners, managers, and employees were categorized, there appeared to be a lack of alignment (Table 5). Employees were most likely to cite how they do their job ("to do my job correctly," "follow the owner's rules") followed by milk quality ("produce high-quality milk," "somatic cells low"), expansion in production or number of cows ("milk 100 cows a day,"

Table 5. Farm goals cited (\%) by owners, managers, and employees ${ }^{1}$

\begin{tabular}{|c|c|c|c|}
\hline Goal & $\begin{array}{l}\text { Owners } \\
(\mathrm{n}=59)\end{array}$ & $\begin{array}{l}\text { Managers } \\
(\mathrm{n}=18)\end{array}$ & $\begin{array}{c}\text { Employees } \\
(\mathrm{n}=246)\end{array}$ \\
\hline Good, safe workplace for employees; efficient, productive, and rewarding work by employees & 22 & 6 & 2 \\
\hline Greater profitability, more efficient production & 21 & 6 & 6 \\
\hline Quality milk, lower SCC & 17 & 28 & 20 \\
\hline Appearance of farm; image in community; reputation; care of assets & 15 & 6 & 2 \\
\hline Healthy, comfortable, well-treated cows & 12 & 22 & 17 \\
\hline Personal rewards; setting up the next generation & 8 & 0 & 0 \\
\hline More cows, more milk & 5 & 33 & 17 \\
\hline Do a good job, keep things clean & 0 & 0 & 29 \\
\hline Don't know & 0 & 0 & 9 \\
\hline
\end{tabular}

\footnotetext{
"What are some of the farm goals you remember?" was an open-ended question (responses were categorized).
} 
"get over 90 pounds of milk per day"), and animal wellbeing ("take care of the animals; don't hurt them," "to keep the cows healthy"). Managers were more focused on the goals of increased production or cow numbers ("milk production," "herd growth") followed by milk quality ("quality," "low SCC") and health and wellbeing of the cows ("overall cow health and comfort," "high pregnancy rate"). Farm owners most often cited employee work ("keep a stable and happy workforce," "good living for everyone") and greater profitability or efficiency ("be profitable," "produce the highest quality product at the lowest cost").

Responses to "How often do you come up with ideas to improve the operation (whether you share those or not)" (Q27) were categorized. The percentage of employees who reported that they either frequently ("Once or twice a week. I have a lot of big ideas, but need a lot of extra and big work," "Often and I share them as much as possible") or occasionally ("Sometimes and I share them with the boss," "Yes, I have ideas. We always have to do our bit") had ideas to improve the business ranged among farms from 44 to $92 \%$ (Figure 2). Overall, the frequency of having ideas to improve the business was lower among Latino employees than English-speaking employees $(P<0.001)$. Similarly, English-speaking employees more frequently $(86 \%)$ than Latino employees $(56 \%)$ reported that they had ideas to improve the business either frequently or occasionally $(P<0.001$; Figure 2). The percentage of employees responding that they had no ideas to improve the business (often stated as "I just do what they tell me to do") was higher among Latino employees (37\%) than among Englishspeaking employees (6\%). Fifteen employees from 6 farms provided a response about ideas to improve the business that distinctly indicated that past attempts had not been received well by management and that, on the basis of that past experience, the employee had ceased to offer any. Examples of that include "Gave up on sharing them; (they) never do anything with my ideas"; "I come up with ideas, but I don't share them, as it is not my business, it's always how they want to run it"; and "I have a lot of good ideas. I don't share them because he thinks we are stupid. He is not open to hear new ideas." These were distributed evenly among English-speaking (8\%) and Latino (10\%) employees.

Employees highly rated their commitment to the success of the farm business (4.62) and whether they would recommend the farm to others for employment (4.13). These are indicators of their intent to be of value to the business.

\section{DISCUSSION}

Because of the importance of employees on large dairy farms, this study was undertaken to determine factors associated with improved employee engagement and lower turnover. Selection criteria for participating farms (interest in employee feedback, voluntary participation, and farm size limitations) made this a nonrandom sample; therefore, results might have been different if farms were chosen from a random sample. Farms in this study achieved high productivity as indicated

\section{- Frequently $\square$ Occasionally $\square$ Never $\square$ No share}

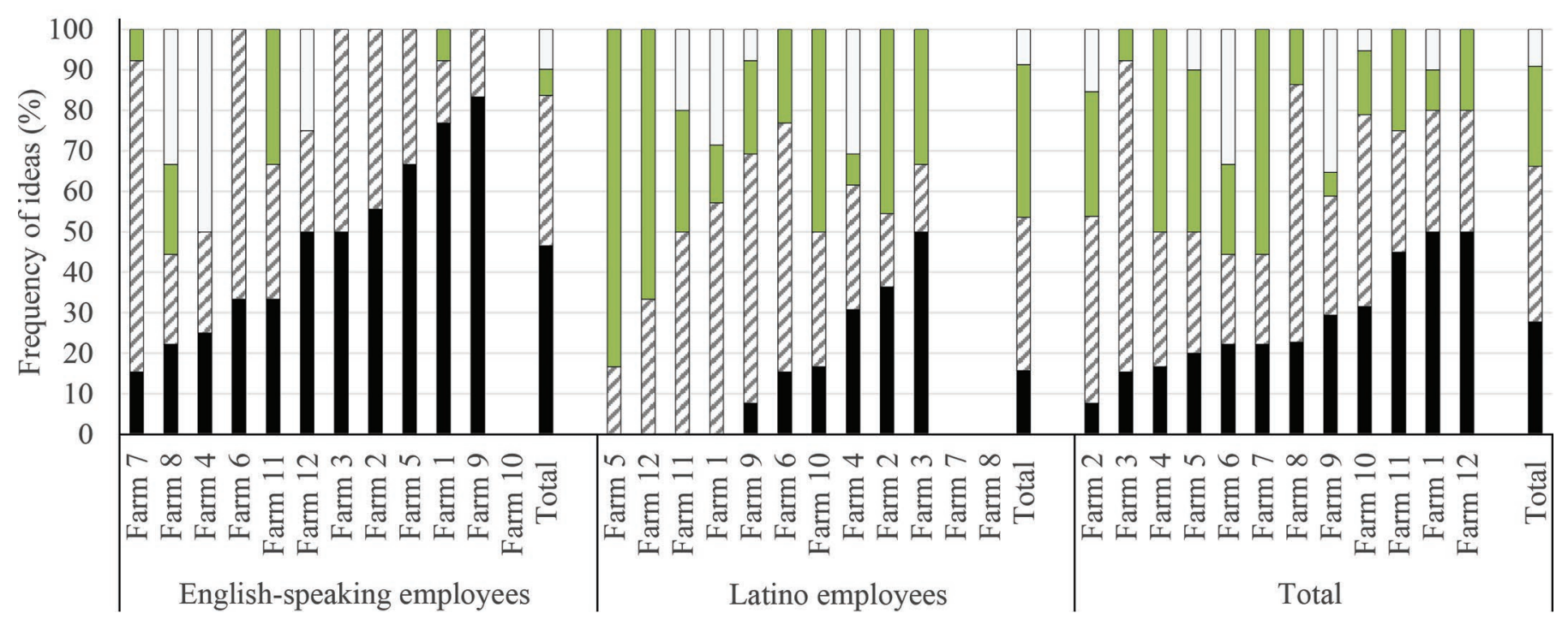

Figure 2. Frequency of employees' ideas to improve the business. Latino $=$ Spanish-speaking $(\mathrm{n}=86)$ and Portuguese-speaking (n $=5$ ) employees. Color version available online. 
by milk production. They were of a size at which they depended on their employees for care and performance of the cattle. Based on production levels, we inferred that they must have high-performing employees. However, some of these farms had much higher employee turnover (Table 1) and shorter employer tenure (Figure 1) than others. Both average employee turnover (59\%) and range (8-144\%) were similar to average employee turnover of $52 \%$ and range of $0-212 \%$ reported by Holub (2002) on Texas dairies of a similar size (average: 964 cows).

Employees who responded that they planned to leave the job within 3 yr were not asked to explain that response. However, we believe that both farm (e.g., ability or inability to advance in position) and nonfarm (e.g., family issues) reasons may have substantial roles. Yet it would be presumptuous to assume that similar situations did not apply across both English-speaking and Latino employees.

The effect of employee turnover on dairy business performance, similar to other businesses, is negative (Billikopf and González, 2012). However, there is complexity to the issue, as apparent in this study. In their meta-analysis, Hancock et al. (2013) did not detect a direct relationship between employee turnover and financial performance. They concluded that the more available replacements are (by skill level, knowledge level, and for the wage offered), the lower the cost of turnover. Likewise, the opposite is true. As dairy production becomes more technical, as quality becomes more important, and as the availability of labor becomes more limiting, the cost of turnover is higher. Whereas the body of literature on employee management and turnover is great (Lambert et al., 2001), relatively few studies have examined effects of dairy farm management on employee effort and tenure and subsequent effects on farm performance. Farms can achieve high production even while having high employee turnover, at least in the short term (Holub, 2002). Even though Holub (2002) did not detect an association between employee turnover and milk production, culling percentage, or bulk tank SCC, he acknowledged that "the success of the total dairy operation depends on managing of the farm's assets, including human resources."

Rosenberg and Cowen (1990) analyzed differences, including employee management, on 87 dairy farms in Tulare County, California (average size: 594 cows), to determine effects on herd production and reproduction. They concluded that all milk production and herd reproduction variables considered were systematically tied to organizational management and stated, "Fat corrected milk was most strongly correlated to management assumptions about worker motivation and amount of feedback given to employees about performance." Although they did not assess employee turnover, it was clear that "employee performance is shaped by organizational structure and personnel management practices, which in turn derive from managerial attitudes, knowledge, and skills" (Rosenberg and Cowen, 1990). Lambert et al. (2001) supported the hypothesis that work environment (measured in 5 dimensions: role conflict, task variety, financial rewards, relations with coworkers, and autonomy/participation) is very important in shaping worker job satisfaction and that it bears a significant effect on the intent to leave a job.

Employee feedback was used as the basis for understanding management on these farms. Their responses to the Likert scale questions, comments, and answers to open-ended questions revealed both strengths and weakness across farms and differences between farms. Good employee management is not all or nothing. In this study, each of the 12 farms scored among the 3 highest for at least 1 Likert management question, and each of the farms also scored among the 3 lowest for at least 1 Likert management question. Mugera (2012) stated, "Organizational outcomes, such as voluntary turnover and termination rates, employee satisfaction, and manager satisfaction, did not stem from single or isolated HRM (human resource management) practices." Therefore, whereas some farms do a better job than others of employee management, no farm does everything right and no farm does everything wrong; rather, they have different strengths and weaknesses to varying degrees. Many facets contribute to good employee management and the ensuing sustained competitive advantage (Mugera and Bitsch, 2005).

Communication was at the heart of weaknesses across farms (performance feedback, training, open and honest communication with supervisors, and communication about goals). Employees want more, and employers do not provide enough; this was true whether employees were Latino or English speaking. In that regard, when employee responses were examined by language group, the lack of difference in many measures was of particular interest. Whereas Latino employees reported better teamwork and clear lines of supervision, it may be helpful to remember that more of these employees worked in the milking parlor rather than around the farm in other roles. There is, however, a difference in what employees reported in regard to providing ideas to improve the operation. For example, Latino employees were less likely to provide ideas to improve the operation. Although culture may have a role (power difference that results in respect for bosses and less likelihood of questioning them; Morales, 2005), differences between farms in the response of employees 
and a lack of difference between employees of shorter job tenure $(\leq 1 \mathrm{yr})$ and those of longer terms imply that farm management is the most important factor. Morales (2005) suggested that when Latino employees "know they are valued, it will be easier for them to contribute ideas to improve the operation."

Difference between language groups in the roles of employees may affect frequency of sharing ideas to improve the operation. Latino employees tended to be primarily in positions of working directly with cattle, whether milking, pushing (moving cows), or some aspect of livestock care. Liebman et al. (2016) noted that "milkers and pushers are relatively routine jobs, with less decision-making than other farm tasks." However, Rosenberg and Cowen (1990) noted that for roles such as milkers, "consistent performance of routine tasks and application of decision rules is critical, but so is alertness and good judgment needed to recognize and adjust to 'exceptions' in the input stream." Milking and livestock care are often entry-level positions. Entry-level workers may not feel free to offer ideas for improvement (and thus responded so in the questionnaire), yet they should be encouraged to do so as it will promote development of their judgment capabilities.

Communication between employees and employers can be complicated by legal status (Liebman et al., 2016). In their interviews with dairy employees, reluctance to report job-related injuries was expressed by employees in relation to a perception that their legal status could be used against them. With communication being such a critical factor, the language barrier between some employees and employers and between employees is an important issue for the full integration of employees. Language is just one issue with communication, and there are nuances even within the same language that reduce effectiveness of communication. Regardless, good communication has an important role in promoting both safety and productivity on farms (Menger et al., 2016). The difficulty that language creates in building teamwork and communication among employees and shift crews was apparent in comments by employees.

Performance feedback is a critical management responsibility, yet the average employee rating for feedback frequency was less than once per month for 11 of the farms (Table 2). When feedback was given as frequently as once per week or month, it was mostly negative feedback, as indicated by employee comments. The question about whether employees had received recognition or praise in the past $15 \mathrm{~d}$ was an interval selected because many farms pay on a weekly or biweekly basis. Therefore, there would be opportunity for interaction as paychecks were distributed. On some farms, at some times, those paychecks would include bonuses. Regardless, the opportunity to provide positive feedback that reinforces good performance was apparently not taken on many farms.

Knowing the goals of the operation, receiving performance feedback on efforts to achieve those goals, and being encouraged to provide ideas for changes to improve the operation are critical elements to fully integrating employees into the business (Milligan, 2017). Having and sharing ideas to improve the business is an important indicator of employee engagement. When employees are thinking about the business and ways that it might improve (irrespective of the validity of their ideas), it indicates that they are concerned about the success of the business and their role in it. However, when employees answer that they have no ideas, they apparently show up for work physically but not mentally. When employees reported that they have ideas but do not share them, it is not just that they have become disengaged but that their disengagement is a direct result of management actions, words, or attitude. Management has a pivotal role in ongoing engagement of employees, as evident by comments from employees. These findings agreed with Medlin and Green (2014), who reported that "both the management principles and management process positively and directly impact employee engagement." When employees do not know goals or when their input is not encouraged, they may feel that they are valued only for their physical efforts or even that they are no more than "donkeys" there to bear the burdens. Recognizing and developing the value of the mind of the employee provides the greatest benefit from employees.

Despite management deficiencies, employees were committed to the success of the farm business. Even though there were shortcomings in key areas of management, employees expressed both satisfaction and a willingness to recommend employment on the farm to others. These are highly positive outcomes and may indicate that employees are willing to endure certain problems for an interval and still remain positive and committed. That is important, as many new employees are attracted due to referrals by current employees.

Farms in this project may not be fully representative of all large US dairy farms because they self-selected to be a part of this study and were paid to participate. That they were willing to do so indicates that they placed an importance on employee management; however, great differences and opportunities for improvement were apparent. The results are employee perceptions. Perception may not equal reality in some areas - for example, training. It may be that employees did not recognize informal training that may be provided regularly. Re- 
gardless, employee perceptions matter. The validity of results was based on the voluntary response level of $79 \%$ of employees from large farms in 4 states. In addition, we believe that respondent anonymity was important to get answers that were as truthful as possible. This was critical not only because employees were evaluating management but because some may not have been legal immigrant workers. Because employees called the interviewer and we encouraged employers to provide opportunity for that at work, it may be that interviews were done on the farm where they worked, in a location provided for that purpose. Liebman et al. (2015) raised the question of a reporting bias when focus groups of employees were held on farm, even though anonymity was guaranteed. In their case, they received more positive responses from the group interviewed on the farm than when interviews were conducted off farm. Certainly, the issue of anonymity is important to employees, especially when their legal status may be in question. With each Likert scale question, employees not only had the opportunity but were encouraged by the interviewer to provide additional information. All employees interviewed, both English speaking and Latino, provided comments beyond the Likert-scale ratings. Difference in roles and length of tenure at the farms between English-speaking and Latino employees complicated a comparison; regardless, overall results detected more similarities than differences.

\section{CONCLUSIONS}

Employees are critical to the success of large dairy operations, and managing employees is a critical role of dairy owners and managers. Turnover of employees on some farms was very high, with job tenure of Latino employees being much shorter than that of Englishspeaking employees. Notwithstanding, employee responses to questions on satisfaction did not differ between employees by language or among farms. There were great differences among farms in how well they managed employees based on the perceptions of their employees. Management of employees involved multiple roles, including goal setting, training, providing tools and performance feedback, clear lines of supervision, and development of a team working for the business. Farms had different strengths and weaknesses in relation to these. Yet, employees cited their own commitment to the success of the business and their own interest in learning about dairy. Despite some differences between English-speaking and Latino employees regarding their responses, similarities were greater, providing a reminder that it is about managing people, not assets.

\section{ACKNOWLEDGMENTS}

This study was supported by the North Central Risk Management Education Center (Lincoln, NE) and USDA National Institute of Food and Agriculture (Washington, DC) under award number 2010-4920006200. Felix Soriano, CEO of APN Consulting (Kinnelon, NJ), was a partner in enrolling and working with herds outside of Michigan. We greatly appreciate the support of all dairy employees, farmers, and managers who participated in this project.

\section{REFERENCES}

Adcock, F., D. Anderson, and P. Rosson. 2015. The economic impacts of immigrant labor on U.S. dairy farms. Accessed Apr. 10, 2018 http://www.nmpf.org/files/immigration-survey-090915.pdf.

Barkema, H. W., M. A. G. von Keyserlingk, J. P. Kastelic, T. J. G. M. Lam, C. Luby, J.-P. Roy, S. J. LeBlanc, G. P. Keefe, and D. F. Kelton. 2015. Invited review: Changes in the dairy industry affecting dairy cattle health and welfare. J. Dairy Sci. 98:7426-7445.

Bewley, J., R. W. Palmer, and D. B. Jackson-Smith. 2001. An overview of experiences of Wisconsin dairy farmers who modernized their operations. J. Dairy Sci. 84:717-729.

Billikopf, G. E. 2003. Labor management in agriculture: Cultivating personnel productivity. Accessed Apr. 10, 2018. https://nature .berkeley.edu/ucce50/ag-labor/7labor/AgLabor.pdf.

Billikopf, G. E., and G. González. 2012. Turnover rates are decreasing in California dairies. Calif. Agric. 66:153-157.

Cabrera, V. E., and J. M. Janowski. 2011. Wisconsin dairy business and production survey: Comparison between farms planning to expand and farms not planning to expand. Accessed Apr. 10, 2018. https://joe.org/joe/2011june/rb1.php/php.

Camarota, S. A., and K. Zeigler. 2016. Immigrants in the United States: A profile of the foreign-born using 2014 and 2015 Census Bureau data. Accessed Apr. 10, 2018. https://cis.org/sites/cis .org/files/immigrant-profile_0.pdf.

Caraviello, D. Z., K. A. Weigel, P. M. Fricke, M. C. Wiltbank, M. J. Florent, N. B. Cook, K. V. Nordlund, N. R. Zwald, and C. L. Rawson. 2006. Survey of management practices on reproductive performance of dairy cattle on large US commercial farms. J. Dairy Sci. 89:4723-4735.

Daouk-Öyry, L., A. Anouze, F. Otaki, Y. D. Nuhad, and I. Osman. 2014. The JOINT model of nurse absenteeism and turnover: A systematic review. Int. J. Nurs. Stud. 51:93-110.

Erskine, R. J., R. O. Martinez, and G. A. Contreras. 2015. Cultural lag: A new challenge for mastitis control on dairy farms in the United States. J. Dairy Sci. 98:8240-8244.

Estrada, J. 2017. Setting goals and using performance feedback effectively. Pages 1221-1229 in Large Dairy Herd Management. 3rd ed. D. K. Beede, ed. Am. Dairy Sci. Assoc., Champaign, IL.

Fuhrman, T. J. 2002. Quality milk starts with quality management. Pages 131-139 in Natl. Mastitis Counc. Ann. Mtg. Proc., Orlando, FL, Natl. Mastitis Council Inc., Verona, WI.

Hadley, G. L., S. B. Harsh, and C. A. Wolf. 2002. Managerial and financial implications of major dairy farm expansions in Michigan and Wisconsin. J. Dairy Sci. 85:2053-2064.

Hagevoort, G. R., D. I. Douphrate, and S. J. Reynolds. 2013. A review of health and safety leadership and managerial practices on modern dairy farms. J. Agromedicine 18:265-273.

Hancock, J. I., D. G. Allen, F. A. Bosco, K. R. McDaniel, and C. A. Pierce. 2013. Meta-analytic review of employee turnover as a predictor of firm performance. J. Manage. 39:573-603.

Holub, G. A. 2002. Effect of labor turnover on dairy production. PhD Thesis. Texas A\&M University, College Station, TX.

Kahn, W. A. 1990. Psychological conditions of personal engagement and disengagement at work. Acad. Manage. J. 33:692-724. 
Kayitsinga, J., R. L. Schewe, G. A. Contreras, and R. J. Erskine. 2017. Antimicrobial treatment of clinical mastitis in the eastern United States: The influence of dairy farmers' mastitis management and treatment behavior and attitudes. J. Dairy Sci. 100:1388-1407.

Lambert, E. G., N. L. Hogan, and S. M. Barton. 2001. The impact of job satisfaction on turnover intent: A test of a structural measurement model using a national sample of workers. Soc. Sci. J. $38: 233-250$.

Liebman, A. K., P. M. Juarez-Carrillo, I. A. Reyes, and M. C. Keifer. 2016. Immigrant dairy workers' perceptions of health and safety on the farm in America's Heartland. Am. J. Ind. Med. 59:227-235.

Maloney, T., L. Eiholzer, and B. Ryan. 2016. Survey of Hispanic dairy workers in New York State 2016. Extension bulletin no. 2016-12. Cornell University, Ithaca, NY.

Medlin, B., and K. W. Green Jr.. 2014. Impact of management basics on employee engagement. Acad. Strategic Management J. 13:2135.

Menger, L. M., F. Pezzutti, T. Tellechea, L. Stallones, J. Rosecrance, and I. N. Roman-Muniz. 2016. Perceptions of health and safety among immigrant Latino/a dairy workers in the U.S. Front. Public Health 4:106.

Milligan, R. A. 2017. Leadership for the farm business. Pages 1179 1187 in Large Dairy Herd Management. 3rd ed. D. K. Beede, ed. Am. Dairy Sci. Assoc., Champaign, IL.

Morales, M. 2005. How to make the most of my multicultural workforce. Pages 22-29 in Proc. 42nd Florida Dairy Prod. Conf. University of Florida, Gainesville.
Mugera, A. W. 2012. Sustained competitive advantage in agribusiness: Applying the resource-based theory to human resources. Int. Food Agribus. Manag. Rev. 15:27-48.

Mugera, A. W., and V. Bitsch. 2005. Managing labor on dairy farms: A resource-based perspective with evidence from case studies. Int. Food Agribus. Manag. Rev. 8:79-98.

Rodrigues, A. C. O., D. Z. Caraviello, and P. L. Ruegg. 2005. Management of Wisconsin dairy herds enrolled in milk quality teams. J. Dairy Sci. 88:2660-2671.

Rosenberg, H. R., and P. Cowen. 1990. Management differences and dairy results. Agribusiness 6:267-279.

Schenker, M., and P. Gunderson. 2013. Occupational health in the dairy industry needs to focus on immigrant workers, the new normal. J. Agromedicine 18:184-186.

Schewe, R. L., J. Kayitsinga, G. A. Contreras, C. Odom, W. A. Coats, P. Durst, E. P. Hovingh, R. O. Martinez, R. Mobley, S. Moore, and R. J. Erskine. 2015. Herd management and social variables associated with bulk tank somatic cell count in dairy herds in the eastern United States. J. Dairy Sci. 98:7650-7665.

Stup, R. E., J. Hyde, and L. A. Holden. 2006. Relationships between selected human resource management practices and dairy farm performance. J. Dairy Sci. 89:1116-1120.

USDA National Agricultural Statistics Service. 2014. 2012 census of agriculture. Accessed Apr. 10, 2018. https://www.agcensus.usda .gov/Publications/2012/Full_Report/Volume_1,_Chapter_1_US/ st99_1_017_019.pdf. 